\title{
The Memory of Katyn in Polish Political Discourse: A Quantitative Study
}

\author{
ROLF FREDHEIM
}

\begin{abstract}
This study uses quantitative methods to explore how the memory of Katyn is mobilised in political discourse. The scholarly literature on memory conflict tends to see international memory disputes as an expression of a state's interests as a whole; this study analyses when hostile rhetoric is mobilised and finds that in Poland Katyn is invoked as part of an opposition strategy that criticises the incumbent regime for undermining the national interest. Periods of accelerated debate about the significance of Katyn have occurred as political elites sought to achieve specific domestic rather than foreign political goals.
\end{abstract}

ON 1 SePtember 2009, EuRope's POLITICAL LEADERS GATHERED at Westerplatte, a peninsula in Gdańsk, and to Poles a symbol of their heroic resistance to Nazi aggression. The occasion - the $60^{\text {th }}$ anniversary of the outbreak of WWII-saw Polish President Lech Kaczyński and Russian Prime Minister Vladimir Putin clash over the memory of WWII. It appeared that Polish and Russian memories of the war were fundamentally incompatible: Kaczyński recalled the brave Polish soldiers who fought against the Germans until 17 September and 'the stab in the back from Bolshevik Russia', while Putin likened the execution of Polish nationals at Katyn to the death of Soviet soldiers in Polish prison camps during the 1919-1920 Polish-Russian war (Sandecki 2009). Kaczyński further claimed that the Red Army's 'treacherous attack' brought 'the night of occupation, the essence of which was the Holocaust, Auschwitz, Katyn. One might ask, what connects Katyn with the Holocaust? The Jews were killed because they were Jews, the Polish officers because they were Poles. Such is the comparison' (Sandecki 2009). In his speech, Kaczyński presented a narrative whereby Poland was attacked by the equal and opposite hostile forces of Russia (rather than the USSR) and Germany that harmed Poland in equal measure. ${ }^{1}$ Such an interpretation was fundamentally incompatible with the Russian view where the Red Army had liberated Europe from fascism and Katyn was merely one of many Stalinist excesses.

The episode at Westerplatte illustrates how debates about history in post-communist Poland and Russia have invaded space normally reserved for foreign policy. Both heads of

\footnotetext{
${ }^{1}$ This narrative is generally accepted in Poland. The Gazeta Wyborcza, normally critical of Lech Kaczyński, espouses the same interpretation; see for instance Radziwinowicz (2009).
} 
state debated the history of WWII and Katyn in order to defend the 'national interest' in historical questions, because a particular historical narrative was fundamental to their conception of national identity. Most studies of identity assume a degree of stability in identity discourse. This article challenges this assumption by tracing the way Katyn was invoked in order to achieve domestic and foreign political goals. The conflict between the nations' representatives at Westerplatte in 2009 was highly visible and contributed substantially to re-igniting international interest in Katyn, ${ }^{2}$ but a closer investigation of the topic will show that the aggressive promotion of provocative historical narratives was associated most strongly with the domestic opposition. This article is one of the first to utilise quantitative methods to map the presence and absence of memory-events in political discourse. $^{3}$

The scholarly literature on memory conflict tends to see international memory disputes as an expression of a state's interests as a whole. This study analyses the circumstances in which hostile rhetoric is mobilised and finds that in Poland the Law and Justice party (Prawo i Sprawiedliwość-PiS) mobilised Katyn as part of an opposition strategy where the ruling party Civic Platform (Platforma Obywatelska-PO) was criticised for undermining the national interest. This article situates the interest of PiS in Katyn in the context of its anti-communist platform, which sought to challenge the Polish post-socialist order. PiS used anti-communist arguments to justify hostility towards Russia more intensively in the run-up to elections and less so immediately following elections. The article concludes that high-level memory squabbles are the product of post-communist elites seeking ideological differentiation in a 'flat' party landscape and only ostensibly about foreign policy. The article has five main sections: first, the intellectual framework and relevant literature are outlined, then the quantitative methods and coding of variables are presented, before examining first the general dynamics of the Katyn discourse in Gazeta Wyborcza and Rzeczpospolita, the distribution of texts specifically critical of Russia, and finally highlighting the distribution of explicit othering arguments.

The Soviet secret police, the NKVD (Narodnyi Kommisariat Vnutrennikh Del), carried out the execution of 21,768 Polish citizens known as the Katyn massacre in April-May 1940. Following the Red Army's entry into eastern Poland on 17 September 1939, 14,600 Polish prisoners of war were taken from the camps of Kozielsk, Starobielsk and Ostaszkow, killed in the Katyn forest outside Smolensk and NKVD prison cells in Kharkov and Kalinin (now Tver'), and buried at sites in Katyn, outside Kharkov, as well as in Mednoye. Another 7,300 prisoners were shot in Belarus and Ukraine as part of the same operation. This series of executions is referred to by the umbrella term 'Katyn'. The majority of those executed at Katyn were Polish reserve officers. According to the law of 9 April 1938 on compulsory conscription, all unexempted graduate students were called up to the army as reserve officers. As a result, those executed included doctors, professors, lawyers and priests (Fischer 2000; Sanford 2005). During perestroika, Boris Yel'tsin conveyed documents proving the NKVD's guilt to the Polish side, and in 2000 a memorial complex was opened at the site of the executions.

\footnotetext{
${ }^{2}$ In 2009 Katyn was mentioned 43 times in The Guardian, compared to an average of three times per year in the period 2000-2008. At the time of the initial revelations in the early 1990s Katyn also figured in the English-language press: in 1990-1995 The Guardian wrote about Katyn on average four times per year. This may seem small, but asymmetry in the digital archives may account for the apparently much greater interest in the late 2000s.

${ }^{3}$ Although precedents exist; see for instance Nikiporets-Takigawa (2013).
} 
The argument at Westerplatte was not the first time Katyn was brought up internationally, but it was the first time the Russian side faced the issue head on. In 2005, Polish opposition politicians cited Katyn as a reason why President Kwaśniewski should not participate in the Victory Day celebrations in Moscow. The 2007 film Katyn, directed by Andrzej Wajda, popularised the debate, made it accessible to international audiences, and revived and reshaped the debate in Poland. The cases brought to the European Court of Human Rights, where victims' families demanded those executed be recognised as war crime victims, were covered in the international media. Katyn gained further international significance following the tragic death of President Kaczyński and his entourage en route to the 70th anniversary Katyn commemorations held in April 2010 near Smolensk, and later that year the Duma officially reiterated Yel'tsin's admission that Stalin was responsible for the massacre.

\section{The existing literature and intellectual framework}

Sheldon Stryker has pointed out that 'Identity remains unproblematised and untheorised in the social science literature' (Stryker et al. 2000, p. 22). Identity can easily become a residual category used to explain any variation unaccounted for by 'universal' models. Especially in constructivist studies of international relations, 'identity' figures as a constant that is said to explain irrational preferences; in other words, identity comes from the bottom up, and the state's representatives are subject to similar beliefs and preferences as the rest of the population. Memory studies, in contrast, have been more open to analysing memory and identity as convenient tools wielded by elites.

Katyn has been the subject of a number of historical monologues. These have dealt with matters of historical truth, such as exposing the NKVD as the perpetrators of the crime (Kisielewski 2008; Fitzgibbon 1972; Montfort 1966; Paul 2010; Stahl \& Anders 1965; Stahl et al. 1949; Trznadel 1994), the willingness of the allies to accept the Soviet cover-up story, despite convincing evidence of their guilt, and the fact that the perpetrators were never punished (Sanford 2005; Wolsza 2008). Little space has been devoted to the role Katyn has played in Polish official discourse and memory politics since 1989. George Sanford, Andrzej Przewoźnik and Jolanta Adamska refer to 'memory' in the title of their studies, but they mean the true memory of the Katyn massacre as opposed to the official lies, not the role Katyn plays in Polish collective memory (Sanford 2005; Przewoźnik \& Adamska 2010). Polish collective memory expert Barbara Szacka refers to Katyn only in passing, highlighting the massacre's role in shifting Polish identity-creation through othering away from Germany and towards Russia (Szacka 2006).

More recently, Katyn has become a paradigmatic case in memory studies. A current project led by Alexander Etkind-'Memory at War'-devoted its inaugural conference to the issue in June 2011, subsequently resulting in a publication (Etkind et al. 2012). The project examines four types of memory conflict: those performed by texts, initiated by individuals, by nation states, and by 'transnational dynamics of culture' (Etkind 2010). An affiliated project at the University of Helsinki focuses on the 'use of history as a political weapon' by state-level actors (Kangaspuro 2010). The 'Memory at War' model examines the political mainly in the clashes of national representatives internationally; this article contends that these clashes may be domestically motivated, and only ostensibly about achieving foreign policy objectives. A number of studies discuss related cases as instances of elite activated memory. These tend to describe ethnically divided nations, where memory 
disputes are blatantly antagonistic to a national majority. For instance, Andrew Wilson explores how rival Russian and Ukrainian historiographies both claimed the Donbas as theirs, which aggravated tensions between the two nations (Wilson 1995). Stuart Burch and David Smith examined Estonia's 'war of monuments' in which the Russian minority's narrative whereby Estonia was liberated by the Red Army is increasingly at odds with official monuments celebrating the Estonian resistance which sometimes bordered on Nazi collaboration (Smith 2001; Burch \& Smith 2007). A common theme is that politicians are willing to shape cultural memory and use antagonistic rhetoric in order to increase their popularity among native Estonians. In April 2007, Prime Minister Andrus Ansip allowed the Bronze Soldier in Tallinn, commemorating Red Army losses in Estonia during WWII, to be removed from the city. On the one hand his popularity soared, but on the other, the Russian minority felt alienated and angry (Brüggemann \& Kasekamp 2008; Burch \& Smith 2007). In Estonia, the effects of antagonistic rhetoric and controversial commemorative practices were clear due to the Other being an internal one that could respond through riots and the national media.

The concept of the Other is fundamental to memory studies, as it is through interaction with the Other that the essence of the Self is made clear (Said 1978). Iver Neumann has argued that 'Russia is liminal to European identity' and the new Eastern European states have portrayed it as a brutal and uncivilised 'Other' (Neumann 2002, pp. 121-25); Katyn features prominently in such arguments in Poland. Here I will heed Jeffrey Olick's call not to 'reinvent the wheel' every time 'we talk in terms of collective memory' (Olick 2008, pp. 27, 26) and instead refer to Olick et al.'s (2011) overview of this literature. Identity emerges in the borderlands where the Self and Other meet, and it is the maintenance of borders that creates identity (Barth 1969). Events that highlight distinctiveness do not emerge by themselves, they are chosen: Habermas and Derrida emphasise that 'historical experiences are only candidates for self-conscious appropriation; without such a self-conscious act they cannot attain the power to shape our identity' (Habermas \& Derrida 2003, p. 295). In other words, elites attempt to shape identity in a particular direction by highlighting one historical experience over another. According to this view, historical events are activated in order to epitomise the nature of the Other and to justify an antagonistic position, rather than expressly as part of foreign policy. Identity forming Othering tends to be discussed as to some degree artificially constructed. Benedict Anderson (1983) and Eric Hobsbawm and Terence Ranger (1983) see national identity respectively as a social or an elite-led construct. Anderson sees identity as imagined, but not as false; to Hobsbawm and Ranger identity is actively created by elites for political purposes, while Ernest Gellner contends that (nationalist) identity is deliberately constructed to satisfy politicians' needs (Gellner 2008). In this top-down view of identity formation elites emphasise an interpretation of historical events that attributes a popular meaning to them, thus gaining legitimacy in the eyes of (at least part of) the electorate, and consequently increasing their (political) power.

In contrast, the constructivist school in International Relations attempted to operationalise national identity as a constant that may account for variation in countries' foreign policy preferences (Jepperson et al. 1996; Aggestam 1999). Identity is held to be 'relatively stable' and formed in discourse ${ }^{4}$ it is maintained by discourse due to ongoing practices that

\footnotetext{
${ }^{4}$ Foucault sees discourse as a set of rules and practices that give a text meaning within a particular context. Discourse is about how knowledge is produced through language (McHoul 1993).
} 
'represent self and other in certain ways' (Wendt 1994, p. 386). Because national identity is maintained in domestic discourse, it influences the state's foreign policy preferences and may explain 'irrational' foreign policy priorities (Larsen 1997, pp. 3-33; Waever 1995). Polish accounts approaching Katyn from a foreign policy perspective tend to narrate the chronology of Russian-Polish negotiations, but lack analysis about Katyn's significance beyond Russia's admission of guilt and the ongoing legal disputes (Kuźniar 2001, 2009; Gil \& Kapuśniak 2009; Madera 2003; Strzelczyk 2002). In practice identity is overwhelmingly described as very stable. The only systematic study applying constructivism to Polish eastern policy was conducted by Sebastian Gerhardt, who based his study on a research design developed by PAFE (Project on the Comparative Analysis of Foreign Policies in Europe), a project conducted at the University of Tübingen (Gerhardt 2007, p. 6). PAFE sees identity as 'a cognitive frame of reference to be activated through social communication processes' (PAFE 2003, p. 1). When analysing Western European states, PAFE found 'an astonishing degree of continuity' in 'foreign policy identities' (Maull et al. 2002, p. 16). In contrast, Gerhardt concluded, there was no one dominant privileged storyteller in Poland and considerable fragmentation in foreign policy discourse (Gerhardt 2007). Gerhardt's study demonstrated how historical events do not yet have a stable position within a Polish identity which is still actively contested. In contrast to scholars highlighting state-level memory conflict, Joanna Gorska presented Polish-Russian relations as characterised by realist concerns, and found constructivist arguments explaining Katyn's significance to be unsatisfactory (Gorska 2010).

\section{An outline of the study}

\section{Hypotheses}

Most broadly, this study attempts to establish whether Katyn is invoked in order to achieve domestic or international results. Identity as operationalised by constructivists is thought of as stable, and state-level actors defend the national interest internationally. Alternatively, identity disputes are sometimes seen as serving individual actors, that is, identity disputes are motivated by the domestic situation. It is hard to distinguish between international and domestic motivation as politicians invariably claim to act in the national interest rather than for personal gain. All this is not to say that individual efforts, historical findings, or judicial proceedings will not affect the significance of the event or the patterns in which it is debated. However, the study does assume that efforts such as those by the Katyn families will be relatively constant, while the voice given to them by politicians at international summits or in sympathetic media outlets may vary. To this end the study examines the presence and absence of statements about Katyn during elections and state visits to unpack the reasons why politicians were interested in Katyn. This leads to the formation of the hypotheses below.

Constructivists such as Wendt (1999) treat foreign policy as an outcome of national identity as already formed within the political community. Actors may pursue ideas internationally even if these undermine 'rational' concerns such as security, since their actions must be acceptable to the national community that shares the identity of which the actors themselves are a product.

This leads to the null hypothesis: the role Katyn plays in identity discourse will be relatively stable over time since it features prominently in a repositioned post-communist identity. 
Alternatively, if identity is considered a tool used by elites, then activating traumatic memory may be thought of as a strategy that has specific costs and payoffs: antagonistically pursuing historical justice and truth in the international sphere comes at the cost of damaging relations with a country's neighbours. Why then do politicians do this?

This leads us to the first alternative hypothesis (1A): political actors invoke contested memories such as Katyn to achieve domestic legitimacy and to achieve a distinctive ideological position. Escalations in memory conflicts will therefore frequently coincide with elections, since contested memories serve a mobilising function.

The costs and payoffs will vary depending on the degree to which actors need to balance the domestic and international consequences of antagonistic discourse.

Consequently I propose an additional hypothesis (1B): the cost of tendentious historical interpretations is high for government actors who seek good relations with their neighbours. Opposition actors are not constrained and therefore are more likely to interpret historical events antagonistically.

\section{Methodology and data collection}

This study uses quantitative methods to test the hypotheses above. Mapping the volume and tone of references to Katyn will document temporal variation in the debate. Multiple linear regression tests control for fluctuations in discourse due to independent variables such as elite statements, annual commemorations, parliamentary and presidential elections, meetings between heads of state, and changes to the domestic political scene. Shocks caused by specific events such as the release of Wajda's 2007 film Katyn are controlled for. Variation in debate immediately before or after elections, or depending on whether PiS was in government or not, will support the alternative hypotheses that the domestic political calendar affects the presence of memory disputes. Similarly, Katyn is often debated at times when Polish and Russian leaders meet. Differentiation in the frequency of mentions at these junctures, depending on whether bilateral relations are good or bad, will also undermine the hypothesis of stability, as if relations are already bad, disputing Katyn is unlikely to jeopardise bilateral agreements.

Political speeches and statements by elite actors provide data for one of the tests, but the sample size is small and the data incomplete, so the test should be seen in conjunction with those drawing on media sources. The main data source is articles in two Polish daily newspapers, the conservative Rzeczpospolita (RZ), and the more liberal Gazeta Wyborcza (GW). The two newspapers contrast strongly in their assessment of PiS and Kaczyński's policies. RZ is used as a proxy for rhetoric associated with the Polish right, while GW figures as a control sample. Major differences between the publication patterns of the two papers are most likely due to different significance attributed to Katyn. It makes sense to use $\mathrm{RZ}$ as a proxy as sympathetic media are the main means for political elites to communicate their stance to the electorate. During the 2000s, changes to the RZ editorial board saw the newspaper align with PiS. After Grzegorz Gauden was named editor in 2004 the paper tentatively moved to the right. Paweł Lisicki was appointed editor in chief in September 2006, and he proclaimed a new course for the paper, declaring that henceforth 'with regards to morals and tradition RZ will be a conservative paper' (Lisicki 2011). Gazeta Wyborcza, in contrast, started out as the mouthpiece of the Solidarity camp. It tends to be more liberal than RZ. GW and RZ have clashed most strongly regarding Solidarity's legacy in Poland's negotiated transition from communism. 
Katyn figures prominently in Polish discourse, therefore no attempt was made at an exhaustive study. Instead, all mentions of Katyn in RZ and GW were collected and grouped by month of publication. A more thorough inspection of the data was aimed at identifying how Katyn was related to arguments about Polish-Russian relations. This was done by mapping the distribution of texts where Katyn was activated as part of an argument hostile to Russia. Peaks in this distribution were then examined more closely, and the patterns of the discourse were examined and contextualised. Keyword searches do not distinguish between articles dedicated to Katyn and other articles referring to Katyn only in passing; such errors should be consistent for the whole dataset, leading to 'white noise' or a relatively large constant, but should not fundamentally affect the results. The chosen method is also problematic in that it does not capture the tone of the debate; a controversial opinion piece will have been more significant than will a passing reference. To counter some of these problems, three searches were conducted: one for the number of articles mentioning Katyn per year, another per month, and a third for articles specifically linking Katyn and Russia. As the latter search yielded fewer results, the data could be analysed and subdivided into three categories: articles sympathetic to Russia, critical of Russia, and articles referring to Russia within the context of an internal Polish debate. The data were limited to the period from January 2000 to March 2010 because of the tragedy at Smolensk in April 2010. While the Russian debate about Katyn arguably only really started after the crash, ${ }^{5}$ in Poland it resulted in the debate moving on: most references to Katyn since have related not to the massacre but to the President's death, while most references critical of Russia have sowed doubt about the Russian investigators' competence or even accused Putin of masterminding the attack. It is too early to tell whether this 'Katyn II', as it was termed, has fully superseded 'Katyn I', but the issue of how the tragedy at Smolensk has been mobilised is a sufficiently different issue to warrant a separate analysis. ${ }^{6}$

\section{When is Katyn debated?}

The null hypothesis posits that identity debates should reveal a degree of stability. To examine this, the number of mentions of Katyn per year is mapped in Figure 1.

The publication history of the two newspapers is very highly correlated (0.96), which suggests the same underlying factors drive the variation in press coverage. In both outlets, the invoking of Katyn was relatively stable until the mid-2000s, whereupon there was a substantial increase in references. The peaks in 1995, 2000 and 2005 are probably accounted for by these being anniversary years (Katyn occurred in 1940), but the subsequent peaks are not explained by anniversaries alone. The same basic pattern was observed when controlling for the total number of articles published, so the growth in the number of articles about Katyn is not due to increased publication or incomplete archival records. A more accurate picture is given by subdividing the annual data into monthly sections (as shown in Figure 2).

\footnotetext{
${ }^{5}$ This is not to suggest that no one in Russia knew about Katyn prior to April 2010, merely to point out that any public debate was limited to liberal opposition newspapers. This is well exemplified by the reporting on Wajda's Katyn in Russia: the film was screened only twice prior to 2010, and mentions of the film in proKremlin publications labelled the film as dealing with World War II tragedies, rather than a massacre conducted by the NKVD. Until 2010 there were only few mentions of who actually was killed at Katyn as ambiguity with the Belorussian village Khatyn, burnt by the Nazis and a Soviet memorial site of Nazi aggression, was rarely avoided if not actively encouraged.

${ }^{6}$ See for instance De Bruyn (2010), and the chapter 'Coda: "Katyn-2"” in Etkind et al. (2012).
} 
Number of mentions of 'Katyń'

O In Rzeczpospolita

In Gazeta Wyborcza

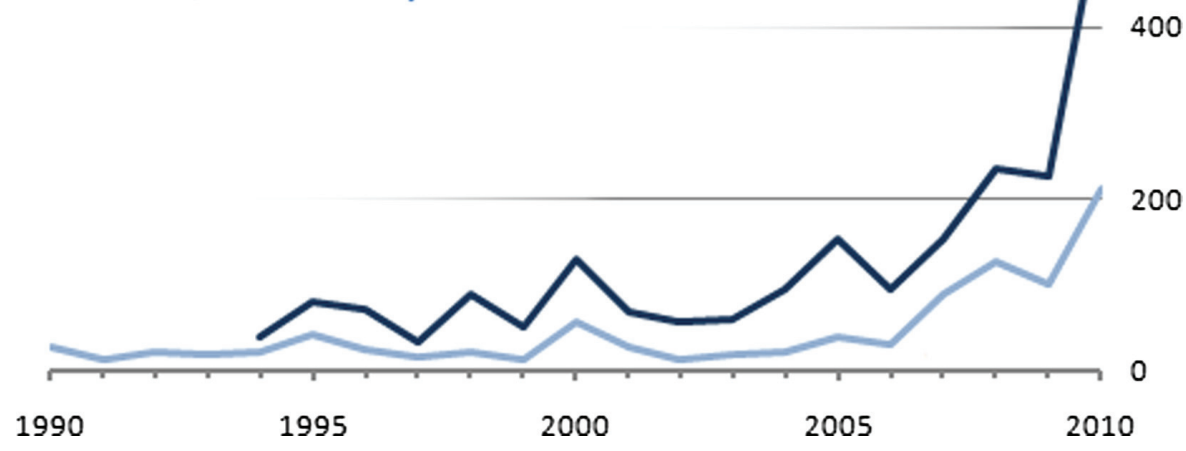

FIGURE 1. Number OF MENTIONS OF ‘KATYN’ PER YeAR, (1990-2010).

Figure 2 reveals a few characteristics of the debate: peaks in the debate have become greater over time, and since mid-2007 Katyn coverage has consistently been high. The escalation of the debate after 2007 suggests that the issue changed from being periodically remembered to becoming an issue of day-to-day import. This corroborates Piotr Kosicki's finding that Wajda's film unleashed a renaissance of memory about Katyn in Poland (Kosicki 2011).

Clearly, GW and RZ have similar but not identical publication patterns. Regression analysis allows an assessment of the degree to which different factors drive debate in papers associated with distinctive political views. In the model provided in Figure 3, variables are grouped into five categories. For the sake of consistency, all variables significant for either dataset were included in all tests.

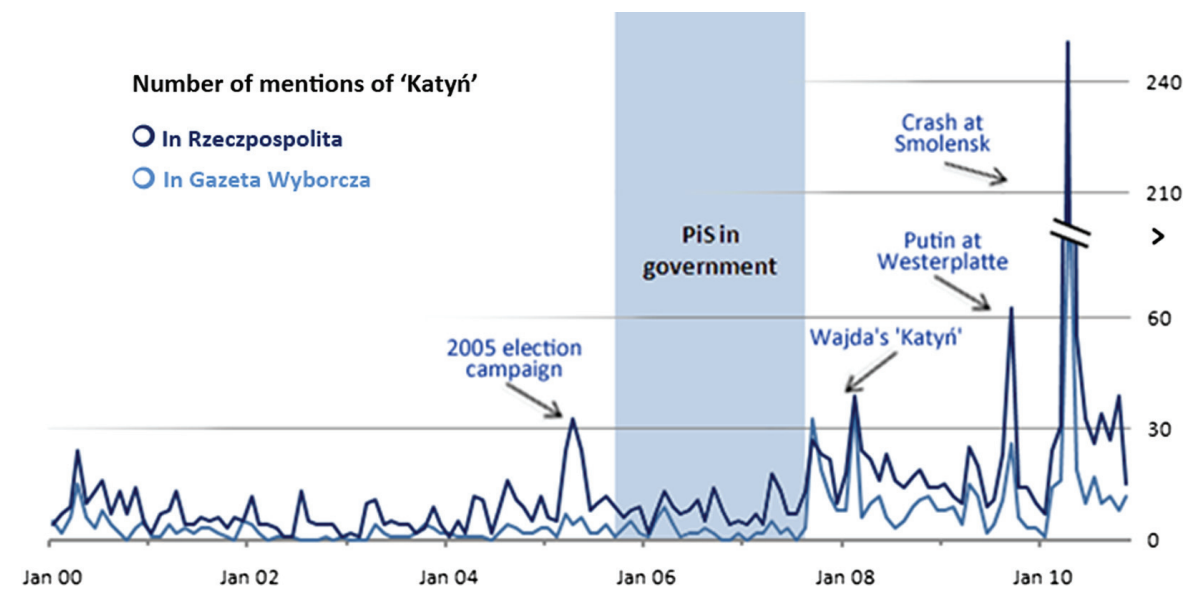

FIGURE 2. MONTHLy FluCtUATION IN Numbers OF MENTIONS OF 'KATYN' (JANUARY 2000-MARCH 2010). 


\begin{tabular}{|c|c|c|}
\hline Group & Variable name & Rationale \\
\hline \multirow[t]{2}{*}{$\begin{array}{l}\text { Shocks as } \\
\text { dummies: }\end{array}$} & Wajda's Katyn & \multirow{2}{*}{$\begin{array}{l}\text { Wajda's film was the topic of many articles at the time of its } \\
\text { release (September 2007), when nominated for an Oscar } \\
\text { (January 2008), and when released in Russia (March 2008). } \\
\text { The lagged variable contols for residual coverage in the } \\
\text { following month. }\end{array}$} \\
\hline & Wajda's Katyn (Lag) & \\
\hline \multirow{3}{*}{$\begin{array}{l}\text { 'Anniversaries' } \\
\text { variables }\end{array}$} & April commemorations & \multirow{3}{*}{$\begin{array}{l}\text { Annual commemorative events lead to more reporting in the } \\
\text { press. Events commemorating Katyń (April 1940) and the } \\
\text { outbreak of WWII (September 1939) are controlled for. }\end{array}$} \\
\hline & $\begin{array}{l}\text { Five-year } \\
\text { commemorations }\end{array}$ & \\
\hline & WWII commemorations & \\
\hline \multirow{3}{*}{$\begin{array}{l}\text { 'Elections' } \\
\text { variables }\end{array}$} & Campaign & \multirow{3}{*}{$\begin{array}{l}\text { Katyń may figure in the run-up to elections as political parties } \\
\text { interpret the event as part of national identity, or invoke the } \\
\text { memory of Katyń to criticise the incumbents. Variables } \\
\text { controlling for election campaigns (last three months before } \\
\text { election), the period following elections (three months after } \\
\text { election), as well as changes in government are included. }\end{array}$} \\
\hline & Change of government & \\
\hline & Election aftermath & \\
\hline \multirow{6}{*}{$\begin{array}{l}\text { 'Bilateral } \\
\text { relations' }\end{array}$} & Russian-Polish crises & \multirow{5}{*}{$\begin{array}{l}\text { Increased conflict over Katyń may be related to external } \\
\text { tensions with Russia. The variable state visit has been split with } \\
\text { one variable capturing visits during periods of normal relations } \\
\text { and another during crises as defined according to the Reuters } \\
\text { factbox of Polish-Russian relations. }{ }^{1} \text { Run-up to state visit } \\
\text { captures the month before a visit; state visit captures month of } \\
\text { visit. }\end{array}$} \\
\hline & Run-up to state visits & \\
\hline & State visit and no crisis & \\
\hline & State visit and crisis & \\
\hline & Tension and no state visit & \\
\hline & 'Russia' in GW & To control for increased publishing about Russia. \\
\hline \multirow[t]{4}{*}{$\begin{array}{l}\text { 'Politics' } \\
\text { variables }\end{array}$} & EU membership ${ }^{2}$ & $\begin{array}{l}\text { Relations with Russia may have changed following EU } \\
\text { accession. }\end{array}$ \\
\hline & Left-wing government & $\begin{array}{l}\text { Left-wing governments may be more inclined to pursue good } \\
\text { relations with Russia. }\end{array}$ \\
\hline & PiS governments & $\begin{array}{l}\text { PiS are credited with pursuing a foreign policy hostile to } \\
\text { Russia. }\end{array}$ \\
\hline & Cohabitation & $\begin{array}{l}\text { Periods where Kaczyński was president but PO were in } \\
\text { government might result in increased ideological conflict } \\
\text { between elite actors. }\end{array}$ \\
\hline
\end{tabular}

Notes: ${ }^{1}$ 'Factbox: Polish-Russian Relations', Reuters, available at: htp://www.reuters.com/article/2010/12/06/us-poland-russia-relations-idUSTRE6B52OL20101206, accessed 6 May 2014.

2 This variable was consistently found to be insignificant and therefore removed.

\section{FIGURE 3. MODEL.}

\section{Results}

These tests are run in order to elicit the circumstances under which Katyn is invoked in discourse. The null hypothesis suggests that Katyn will be invoked in a relatively stable manner. The 'anniversaries' variables should therefore be of the greatest significance. The alternative hypotheses suggest that specific domestic and international payoffs inform the degree to which Katyn figures in discourse. Table 1 displays how much variation each cluster of variables can explain in isolation for the GW dataset. The results for RZ were substantially similar. Domestic and international variables both have some explanatory power, while the elections and anniversaries variables do not. 
TABLE 1

Katyn in Gazeta Wyborcza, January 2000-March 2010, 746 TeXts

\begin{tabular}{|c|c|c|c|c|}
\hline & Anniversaries & Elections & Russia & Political \\
\hline April commemorations & 1.59 & & & \\
\hline 5-year commemorations & 3.59 & & & \\
\hline WWII commemorations & 2.11 & & & \\
\hline Campaign & & 0.80 & & \\
\hline Change of government & & 3.64 & & \\
\hline Election aftermath & & 0.31 & & \\
\hline Russian-Polish crisis & & & -1.53 & \\
\hline Run-up to state visit & & & 1.29 & \\
\hline State visit \& no crisis & & & -0.52 & \\
\hline State visit \& crisis & & & $7.44^{*}$ & \\
\hline Tension \& no state visit & & & -2.81 & \\
\hline Russia in Gazeta Wyborcza & & & $0.05^{* *}$ & \\
\hline Cohabitation & & & & $4.47^{*}$ \\
\hline Left-wing government & & & & -2.45 \\
\hline PiS government & & & & -0.82 \\
\hline Poland in EU & & & & 1.41 \\
\hline Constant & $3.79 * * *$ & $4.36^{* * *}$ & -1.49 & $3.81 * * *$ \\
\hline Adjusted R squared & 0.022 & -0.014 & 0.107 & 0.249 \\
\hline
\end{tabular}

$* \mathrm{p}<0.05, * * \mathrm{p}<0.01, * * * \mathrm{p}<0.001$

The period of cohabitation is associated with an increase in mentions of Katyn, as are state visits during times of tension. The nested model in Table 2 shows how the variables complement each other.

The 'anniversaries' and 'elections' variables, found to be insignificant in isolation, contribute significantly to the overall picture. Adding the 'Wajda' variable more than doubles the adjusted $r$-squared score, so it should be remembered that throughout this study high $r$ squared scores are the result of being able to account for the increased publication that accompanied the film's release. All groups of variables appear to have some explanatory power: the 'cohabitation' variable remains highly significant, while meetings during periods of tension are also associated with more frequent mentions of Katyn. The importance of elections is less clear: there appears to be an increase in references at times when governments have changed, though this is not the case for the run-up to or the aftermath of an election. It is interesting to note some of the variables that are insignificant: there is no increase associated with PiS's term in office or during periods of tension and crisis. These findings suggest that variation in the debate is non-random. The RZ data suggest similar relationships. RZ mentioned Katyn more frequently than GW, so one would expect on average higher coefficients. Comparatively the paper devoted less attention to Wajda's Katyn, but substantially more to state visits. In particular, the run-up to state visits, as well as visits during periods of good relations, are significant explanatory variables for RZ's publishing patterns. Again, the period of cohabitation emerges as one of intensified debate. Unlike in the GW sample, changes in government were not significant. Particularly the variation in the 'state visits' variables suggests that the international dimension is approached differently depending on political orientation. Similarly, the 'state visits' variables demonstrate that acceleration in the Katyn debate is most common at times of Polish-Russian crises. Cumulatively these findings suggest that the debate is not as stable as the null hypothesis 
TABLE 2

Katyn in Gazeta Wyborcza and Rzeczpospoltta, January 2000-March 2010, Nested MODEL

Katyn in Gazeta Wyborcza

Katyn in Rzeczpospolita

January 2000-March January 2000-March 2010, 746 texts 2010, 1812 texts

\begin{tabular}{|c|c|c|c|c|c|c|}
\hline & Political & Russia & Anniversaries & Elections & All & All \\
\hline Cohabitation & $4.47 *$ & 2.91 & 4.65 & $6.75^{*}$ & $5.46^{* *}$ & $7.65 * *$ \\
\hline Left-wing government & -2.45 & -2.40 & -1.63 & -0.24 & -0.86 & -0.98 \\
\hline PiS government & -0.82 & -0.59 & 1.02 & 2.53 & 0.45 & -0.71 \\
\hline Poland in EU & 1.41 & 1.94 & 0.99 & 0.08 & 0.03 & 2.98 \\
\hline Russian-Polish crisis & & 1.01 & -0.77 & -0.63 & 0.25 & -0.11 \\
\hline Run-up to state visit & & 0.88 & 0.38 & 1.32 & 1.15 & $5.70 * *$ \\
\hline State visit \& no crisis & & 0.31 & 1.07 & 1.03 & 1.90 & $5.97 *$ \\
\hline State visit \& crisis & & 6.00 & 4.43 & 5.02 & $6.34 * *$ & $20.06 * * *$ \\
\hline Tension \& no state visit & & 2.59 & -2.36 & -3.37 & -2.87 & -2.19 \\
\hline Russia in Gazeta Wyborcza & & 0.03 & 0.03 & 0.03 & 0.01 & -0.02 \\
\hline April commemorations & & & 1.95 & 2.23 & $2.62 *$ & $7.81 * * *$ \\
\hline 5-year commemorations & & & 3.54 & $4.07 *$ & $3.70 * *$ & $6.81 * * *$ \\
\hline WWII commemorations & & & 1.64 & 0.52 & 0.53 & 2.10 \\
\hline Campaign & & & & $3.51 *$ & 1.04 & 1.59 \\
\hline Change of government & & & & $6.07 *$ & $4.89^{*}$ & 1.47 \\
\hline Election aftermath & & & & 0.04 & 0.68 & -1.35 \\
\hline Wajda's Katyn & & & & & $29.30 * * *$ & $20.70 * * *$ \\
\hline Wajda's Katyn (lag) & & & & & $5.14^{*}$ & $12.30 * *$ \\
\hline Constant & $3.81 * * *$ & 0.44 & -0.36 & -2.04 & 1.13 & $7.34 * *$ \\
\hline Adjusted R squared & 0.249 & 0.271 & 0.292 & 0.317 & 0.744 & 0.670 \\
\hline
\end{tabular}

$* \mathrm{p}<0.05, * * \mathrm{p}<0.01, * * * \mathrm{p}<0.001$

suggested, as well as showing that compared to GW, RZ is more interested in the political than the cultural and commemorative aspects of Katyn.

\section{Katyn in party ideology}

During the 1990s the Polish party system was highly volatile, with few parties other than the post-Soviet SLD (Sojusz Lewicy Demokratycznej) displaying any continuity between electoral cycles. In 2001 the SLD together with the UP (Unia Pracy) entered a coalition government. The 2005 election saw the decline of the left-wing SLD, and the permanent fracturing of the post-Solidarity block into PO and PiS. As the communist successor party became less significant as the main political opposition, the post-Solidarity parties $\mathrm{PO}$ and PiS realigned themselves against each other. At this time observers began to characterise Poland as a two-party state, as PO and PiS between them held the vast majority of seats in the Sejm. ${ }^{7}$ In 2005 PiS entered coalition government with the more radical Samoobrona (Self Defence) and LPR (Liga Polskich Rodzin). The coalition did not last long though, and both of these parties disappeared from the Polish political landscape. In both the 2007 and 2011 parliamentary elections PiS and PO between them gained $70 \%$ of the vote.

\footnotetext{
${ }^{7}$ See for example Markowski (2006).
} 
Both PiS and PO trace their routes to the Solidarity movement and occupy a similar position on the left-right spectrum, but they differ in their attitude to the communist legacy and the negotiated transition. The parties disagree about the nature of the communist legacy, and PiS has mobilised Katyn as epitomising communist crimes against the nation.

PiS, founded by the twins Jarosław and Lech Kaczyński in 2001, drew on the Church's teachings, Polish traditions, and Poland's historical experiences as its main intellectual sources. PiS vehemently rejected the negotiated compromise from communism, a view first expressed by Jan Moczulski and the Konfederacja Polski Niepodległej (Maj \& Wójcik 2008, pp. 16-19, 36). To Moczulski, the 1989 Round Table discussions led by Tadeusz Mazowiecki were an act of treachery, as the legal structure of the PRL (Polish People's Republic-Polska Rzecspospolita Ludowa) could not form the basis for a post-socialist system. Key Solidarity actors had been compromised by contact with the communist authorities, and a vetting system (lustration) was needed to ensure that anyone tainted was kept away from political office (Maj \& Wójcik 2008, pp. 16-19, 36). PiS's vision saw Poland as threatened by two eternal foes, Russia and Germany, who sought to destroy any independent Poland. For this reason Polish foreign policy should therefore be aimed against these two neighbours (Maj \& Wójcik 2008, pp. 44-45, 102). In 2003 Paweł Śpiewak re-launched the term 'IV Republic', claiming a new Republic was needed to eradicate the ills society had suffered during the accelerated transformation from communism (Śpiewak 2003). In March 2005, PiS embraced the idea as part of a new 'Polish Constitution' during their parliamentary election campaign. The IV Republic's Constitution had its 'foundation in anti-communism' (PiS 2003) and called for 'the renewal of morality in public life', 'the fighting of corruption', and the 'removal of Communist agents' from positions of authority (Gmyz 2010). ${ }^{8}$ According to PiS, the system (uktad) that seized power in the early 1990s was dominated by a post-communist elite made up of secret agents, politicians, interest groups and business. The uktad was to blame for the ills of modern Poland, and became the target of the Kaczyńskis' political efforts (Bartoszewski \& Süssmuth 2008, p. 7; Kaczyński 2006).

To PiS, Katyn became the main symbol that epitomises communist crimes against Poland, and as Lech Kaczyński made clear at Westerplatte, ought to be seen as a symbol parallel to Auschwitz. For this reason PiS were at the forefront of the call to acknowledge the events at Katyn as genocide. The term genocide implies that the purpose of Katyn was to cripple the Polish nation, and was therefore the most extreme case of the general Soviet policy towards Poland, and similar to that of Nazi Germany according to which Poles were Untermenschen (Wildstein 2009). Illustrative of the emergence of the anti-communist memory of the war was PiS's promotion of the equal commemoration of 17 September, the date of the Soviet invasion, and 1 September, the day the Nazis invaded Poland. In the early 2000s, Poles did not associate the date 17 September with any particular event, but by 2008 , $50 \%$ of Poles were able to identify it as the date the Soviet Union invaded Poland. Yet, this fact was given negative spin in Rzeczpospolita, where one author lamented how only one in two Poles knew the significance of this date (Zdort 2008). This ignorance was attributed to poor 'memory work' by the III Republic's elites. The fact that only in 2007 had a film been

\footnotetext{
8'IV Rzeczpospolita', Rzeczpospolita, 15 December 2005, available at: http://wiadomosci.wp.pl/ kat,43834,title,IV-Rzeczpospolita,wid,8118743,wiadomosc.html?ticaid=112a7b, accessed 10 April 2011.
} 


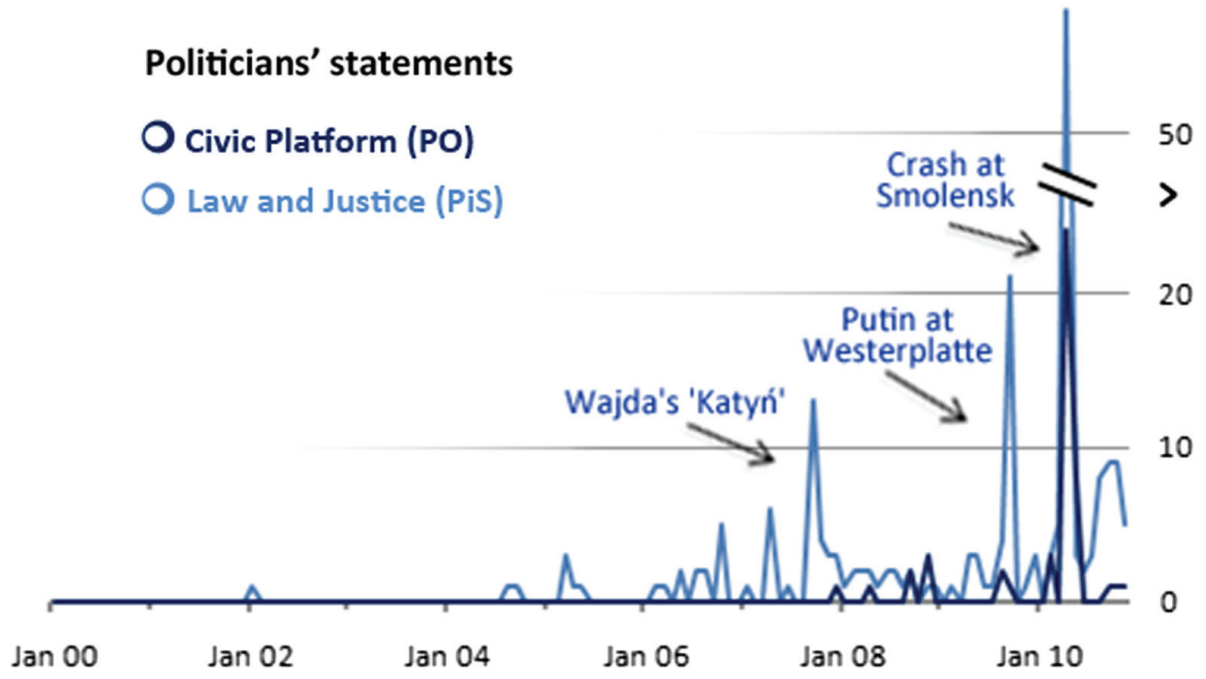

FIGURE 4. NUMBER OF REFERENCES TO 'KATYN’ BY POLITICIANS (JANUARY 2000MARCH 2010).

made about Katyn exposed the authorities' negligent approach to the memory of Soviet aggression (Stróżyk 2008).

Data were also collected from PiS press releases that mentioned Katyn. It should be noted that the data are incomplete for the period prior to 2006. Figure 4 shows that PiS has commented on the issue more frequently during the decade, while, with the exception of April 2010, PO rarely referred to the issue. This variation in interest by the two parties contributes to disproving the stability hypothesised.

Table 3 confirms that PiS have been more vocal since leaving government; this is indicated by the 'cohabitation' variable's coefficient being higher and more significant than the 'PiS government' variable. Tensions with Russia are not in themselves significant, but state visits and crises are the best predictor of the pronouncements of PiS on Katyn, showing that antagonistic statements about Katyn tend to occur when relations are already bad.

There was a notable acceleration in Katyn debates somewhere in the middle of the decade. If discourse was stable then the 'anniversaries' variable should have relatively stable explanatory power. When limiting the regressions to 2000-2006, the 'anniversaries' variables explain $35 \%$ of the variation in the RZ data and $25 \%$ of the variation in the GW data. For the decade as a whole, these variables explain only $12.5 \%$ and $2.2 \%$, respectively. We noted above that until the mid-2000s the 'commemoration' variables had good explanatory power, but that this changed. It seems that political elites, in particular those associated with PiS, escalated the debate; only this can account for the prominence of Katyn in the Polish press since 2006. PiS's statements may be contrasted with PO's: the adjusted $r$-squared score is very low for the latter, and overall the variables have limited explanatory power. PiS have therefore more actively invoked Katyn at key junctures than have PO. This variation shows that some actors are more inclined to invoke memory of national trauma than others. Figure 4 shows that PO's coverage was relatively stable while PiS's escalated. 
TABLE 3

Variables Explaining Variation in Parties' InTERest

Law and Order (PiS) January 2000-

Civic Platform (PO), January 2000March 2010, 212 texts March 2010, 48 texts

\begin{tabular}{lcc}
\hline & All & All \\
\hline Cohabitation & & $0.53^{*}$ \\
PiS government & $2.03^{*}$ & 0.10 \\
Poland in EU & 1.27 & -0.12 \\
Russian-Polish crisis & -0.10 & 0.24 \\
Run-up to state visit & -0.30 & -0.07 \\
State visit \& no crisis & 0.95 & -0.30 \\
State visit \& crisis & -0.85 & 0.05 \\
Tension \& no state visit & $6.37 * * *$ & $-0.71^{*}$ \\
Russia in Gazeta Wyborcza & -1.45 & 0.00 \\
April commemorations & -0.01 & 0.03 \\
5-year commemorations & 1.04 & 0.42 \\
WWII commemorations & 0.51 & 0.37 \\
Campaign & $1.84^{*}$ & 0.02 \\
Change of government & 0.22 & 0.58 \\
Election aftermath & 1.42 & 0.02 \\
Wajda's Katyn & 0.06 & -0.40 \\
Wajda's Katyn (lag) & $5.47^{* *}$ & -0.50 \\
Constant & 1.29 & -0.36 \\
Adjusted R squared & 0.29 & 0.151 \\
\hline
\end{tabular}

$* \mathrm{p}<0.05, * * \mathrm{p}<0.01, * * * \mathrm{p}<0.001$

The hypotheses positing stability on the one hand and political calculation on the other are thus not mutually exclusive; it would seem Katyn has become increasingly significant to $\mathrm{PiS}$, while to $\mathrm{PO}$ its significance has remained relatively stable. Thus, the null hypothesis is appropriate for explaining PO's interest, while additional factors such as those stipulated in the alternative hypotheses are needed to explain PiS's usage. As the data are incomplete these conclusions cannot be drawn too far, but it should be clear that Polish political parties approach Katyn very differently.

\section{Katyn and criticism of Russia}

Katyn features in discourse critical of Russia due to the idea that Poland was equally the victim of Soviet and Nazi aggression. Thus far we have seen that political actors are more likely to speak about Katyn if relations with Russia are already bad. In this next section the articles mentioning Katyn in relation to Russia were subdivided into those broadly sympathetic to and those critical of Russian actions and by implication the Russian state. Examining these more closely reveals that intensified criticism of Russia was due more to disputes with Polish liberals than to Russian actions. Gazeta Wyborcza frequently criticised PiS for its insensitive comments, while RZ criticised GW for being excessively 'Russophile'. These findings demonstrate that PiS focuses on Katyn in order to illustrate why good relations with Russia are impossible.

Critical articles in RZ, displayed in Table 4, are best explained by the 'state visits' variable, cohabitation, and election aftermath. Critical opinions were thus less frequently 
TABLE 4

Coverage about Katyn and Russia in RZeCZPospolita

\begin{tabular}{lcc}
\hline & Critical 273 texts & Sympathetic 211 texts \\
\hline Cohabitation & $3.22 * *$ & 1.01 \\
Left-wing government & 0.36 & 0.22 \\
PiS government & 0.59 & 0.56 \\
Poland in EU & 0.41 & -0.37 \\
Russian-Polish crisis & 0.74 & -0.31 \\
Run-up to state visit & $2.10^{* *}$ & 0.67 \\
State visit \& no crisis & 0.54 & $2.45^{* * *}$ \\
State visit \& crisis & $10.37 * * *$ & 0.70 \\
Tension \& no state visit & -0.59 & 0.30 \\
Russia in Gazeta Wyborcza & $-0.02 *$ & -0.00 \\
April commemorations & 0.25 & 0.17 \\
5-year commemorations & $1.56 *$ & $2.40^{* * *}$ \\
WWII commemorations & 0.39 & -0.37 \\
Campaign & 0.08 & 0.16 \\
Change of government & -0.07 & -0.04 \\
Election aftermath & $-1.46 *$ & -0.63 \\
Wajda's Katyn & 0.67 & $2.28^{*}$ \\
Wajda's Katyn (lag) & 0.44 & 1.69 \\
Constant & 1.67 & 0.76 \\
Adjusted R squared & 0.582 & 0.284 \\
\hline
\end{tabular}

$* \mathrm{p}<0.05, * * \mathrm{p}<0.01, * * * \mathrm{p}<0.001$

aired immediately following elections and more frequently when PiS was in opposition. It is interesting to note that the 'election' variables are significant for critical articles, but not for the data as a whole. This suggests anti-Russian rhetoric featuring Katyn is disproportionately invoked during elections, rather than purely as part of identity debates. These findings support the suggestion that criticism of Russia is driven more strongly by the domestic political calendar than coverage of Katyn as a whole.

\section{Is the target of criticism actually Russia?}

To highlight the dynamics of the Polish debate the month with the largest number of articles critical of Russia was examined. Twenty-four such articles appeared in September 2009, at the time both of Putin's arrival at Westerplatte and the 17 September commemorations. In both cases, Katyn was discussed extensively in the media, not because Russia made an unambiguously hostile move or due directly to commemorations, but because their significance was internally disputed. A closer look at the argument in these two cases will highlight that the debate is only ostensibly about Russia; actually, it relates to the adequacy of the Polish government's foreign policy.

The controversy surrounding the wording of the Sejm's resolution on Soviet aggression was important because the basis for Polish-Russian relations was disputed: PiS was keen to make Katyn the bottom-line in bilateral talks, while PO was more concerned about ensuring the talks were productive. Lech Kaczyński called for the resignation of the Sejm's vice-marshal Stefan Niesołowski for 'exceeding all standards of disloyalty to his country' after the latter suggested there had been only two examples of genocide in history: the Holocaust and the 
holodomor in Ukraine. ${ }^{9}$ The view that Katyn was genocide is based on a particularly inimical view of communism: 'Hitler's goal, as Stalin's ... was the destruction of Polish national identity ... and Katyn was only one element of that project common to the Soviets and Nazis' (Terlikowski 2009). RZ presented opinion polls claiming that $61 \%$ of Poles supported PiS's demand that Katyn be classified as genocide, and asked rhetorically whether the politicians would abide by the will of the people (Gmyz \& Stróżyk 2009). PO's reluctance to accept the project led PiS to criticise their 'soft-policy' towards Russia (Manys 2009). In this way PiS categorised its position on Katyn as the centre ground from which the government made concessions. Commentators such as Bronisław Wildstein wrote that the absence of the word genocide would signify a Polish retreat on this issue, and went on to criticise PO's 'historical politics' (Wildstein 2009), while Marek Domagalski went further, claiming that 'denying Katyn the attribute genocide is an outrageous, unjustified revision of general knowledge on that topic' (Domagalski 2009). Despite an embarrassing episode where the head of the Federacja Rodzin Katynskich, an organisation PiS purported to support, went on record saying that Katyn need not be classified as genocide (Kołakowska 2009), President Kaczyński publicly claimed Katyn was genocide and the product of 'great-Russian chauvinism' (Wybranowski 2009).

Putin's visit was controversial because Polish politicians were divided as to its significance: did his conciliatory statements belittle Poland, or were they a positive step? Mariusz Błaszczak, PiS's spokesperson, protested against Putin's wording, while Paweł Graś, representing the government, considered Putin's message a positive one, albeit not entirely in accord with Polish interpretations (Kubiak \& Wybranowski 2009). RZ was keen to show how inadequate Putin's statement was: he had placed too much emphasis on the Red Army freeing Poland, placed the People's Army (Armia Ludowa) on the same level as the Home Army (Armia Krajowa), as well as making reference to Soviet losses in Polish prisoner of war camps in 1919-1920 (Zychowicz 2009). Rather than embracing a change of rhetoric, PiS emphasised how Moscow sent contradictory messages (Prus 2009), and RZ editor Lisicki termed Putin's call for 'mutual forgiveness' 'scandalous' (Lisicki 2009). Kaczyński directed his speech at Westerplatte against the Russian delegation through poorly veiled references to Russia's 'neo-imperialist' attack on Georgia in 2008. After Kaczyński apologised for the Polish occupation of Czechoslovakian territories in 1938 (most notably the town of Cieszyn), he asserted that 'we Poles are able to confess our sins', and 'we Poles have the right to access the truth', before ending his speech directly criticising the comparison of Katyn to Red Army deaths in 1920 as 'hindering reconciliation' (Kaczyński 2009). Tusk, in his speech, stated unambiguously that the Molotov-Ribbentrop pact had led to war in Poland, but reminded his listeners that it was not the prime minister's role to 'conduct a historical dispute'. He mentioned that Westerplatte, the Molotov-Ribbentrop Pact, and Katyn were historical facts that might be 'differently assessed' but never disputed (Uhlig 2009).

Hypothesis 1B suggests that the cost of aggressive foreign policy rhetoric is different for ruling and opposition groupings as ruling elites have to deal with the external ramifications. The president's role, though significant, is largely a symbolic one in Poland, but he does have a say in foreign policy and frequently attends summits and bilateral meetings. During the period of cohabitation, PiS used the office of the president to promote a more aggressive foreign policy to the detriment of the government's eastern policy. Evidence for this is

\footnotetext{
9،“'Chcemy odwołania Niesiołowskiego”', Rzeczpospolita, 10 September 2009, available at: http://www. rp.pl/artykul/361166.html, accessed 29 March 2011.
} 
provided by opinion polls: in $2008,86 \%$ of Poles felt government and president failed to cooperate in the sphere of foreign policy (Strzeszewski 2008, p. 3). Over the next two years, as a result of the conflict between president and government, Katyn was perceived as an ever larger problem: in 2008, 67\% of respondents felt Katyn hindered normal Polish-Russian relations, a figure that grew to $81 \%$ in 2010 (Pankowski 2010, pp. 2-6).

\section{Russia the Other as an opposition strategy?}

In this final section the dataset is further refined as texts that clearly employ an othering strategy, equating Poland with truth and Russia with lies, are highlighted. It demonstrates that the most aggressive rhetoric is clustered around Polish elections.

In initial tests, elections did not appear to be the most significant factor underlying the debate. Nonetheless, they did matter, as illustrated by the controversy surrounding the failure of the EU parliament to observe a one minute's silence in 2005, timed to precede the legislative and presidential elections later that year. Similarly, PiS's campaign against Kwaśniewski's visit to Moscow took place shortly before the 2005 parliamentary elections. A PiS party political broadcast in May 2005 on Polish state television stated: 'Hitler and Soviet Russia's attack cost us six million people and half a century of enslavement. Now Russia would have us thank them for Yalta'. Then the broadcast moved on to Katyn: 'Moscow refuses to classify this crime as genocide'. Lech Kaczyński then said the president should not go to Moscow because 'today Russia wants to humble Poland because we can't be ordered about' (Majda 2005). The Russian foreign office even protested against the broadcast, an act which Kaczyński described as 'meddling with internal Polish affairs' (Majda 2005). PiS pushed emotionally charged issues, such as Russia's reluctance to reopen the Katyn case, in order to receive wider pre-election coverage. The extensive references to Katyn as the cornerstone of Polish-Russian relations was part of a campaign directed against the post-communist party SLD and incumbent President Aleksander Kwaśniewski. Hypothesis 1A states that historical memory may serve a mobilising function, while hypothesis 1B suggests opposition actors are more likely to exploit this. Revisiting Figure 2, which compares GW and RZ publication patterns, reveals that in early $2005 \mathrm{RZ}$ had an anomalous peak in coverage of Katyn. The shaded area representing PiS's period in government in Figure 2 confirms that that coverage was consistently low during this period, as none of the major peaks in discussion fell within PiS's term in government. The impression that pushing the Katyn question specifically, and historical memory more generally, was a tactic employed by PiS when in opposition is inescapable.

In April 2005, Katyn was used on the Polish side of a value-laden division between Polish and Russian interpretations of the War: the Russian Victory celebrations in May emphasised Soviet heroism, while Katyn showed Russian treachery, lies and denial. The division between Russian lies and Polish truth became embedded in the rhetoric surrounding Katyn. Titles such as 'Crime, lies, silence, truth', 'Years of fighting for the truth', 'They testified to the truth', 'Only the truth', 'Between two enemies', and 'Moscow does not believe in tears' illustrate the rhetoric used (Kaczyński 2005a, 2005b; Marzec 2005; Ordyński 2005; Adamska 2005; Łętowski 2005). In May 2005, Russia was accused of being responsible for the outbreak of WWII and reinstating the Stalin cult. Soldiers in the victory parade were described as 'Russian mercenaries who murdered and tortured the Chechens (willingly and for pay)' (Kurczab-Redlich 2005), and the Russian army's intervention in Chechnya was 
likened to the NKVD's crimes against Poles. Increasingly 'Russian' and 'Soviet' were used interchangeably (Piwowar 2009); in a party broadcast Lech Kaczyński spoke of Soviet Russia rather than the Soviet Union (Majda 2005). The Soviet Union and Nazi Germany were presented as equally responsible for Polish wartime losses and the war itself, while Katyn and Yalta featured as negative slogans. Throughout, PiS employed emotive terms such as 'enslavement', 'genocide', 'humiliation', and 'meddling' when discussing Russia and the USSR (Majda 2005). The term Katyn symbolised communist and Russian crimes against Poland, and became an automatic response to attempts at relativising the merits of the PRL or acknowledging the Red Army's war effort.

PiS is frequently categorised as a 'populist' party (Rupnik 2007; Vachudova 2008; Bachmann 2006), so it is unsurprising that the party is associated with discourse antagonistic to Russia. Hypothesis 1B posits that such rhetoric is most attractive to opposition figures. The analysis of the discursive change in Rzeczpospolita and PiS rhetoric, along with the increasingly monotonous characterisation of Russia, allows closer analysis of patterns of critical coverage. One feature of the 'othering' discourse used is a binary contrast where Poland is associated with truth and Russia with lies. To capture this all articles containing 'Katyn' and 'Russia' were filtered by the keyword 'lies'. In Rzeczpospolita's archives, there were 97 articles from the period 2000-2010 mentioning all three terms, while GW contained only nine articles. I filtered these results further to include articles only critical of Russia. This left 50 articles which represent a general trend; similar wordings will have been excluded by the search criteria. The sample size is relatively small so a cumulative average was used to capture the level of discourse and specifically the number of articles published in the previous six months in any given month (see Figure 5).

Figure 5 shows that the periods when this particular discourse was activated fell outside PiS's term in government. The discourse was mobilised during the 2005 and 2010 elections, as well as during the period of cohabitation. Regressions for these data suggest that these findings are statistically highly significant (see Table 5).

In Table 5 some findings are immediately striking: the election variables are statistically significant and show that this type of discourse increases sharply in the run-up to an election and disappears equally sharply following it. The coefficients for the 'government' variables

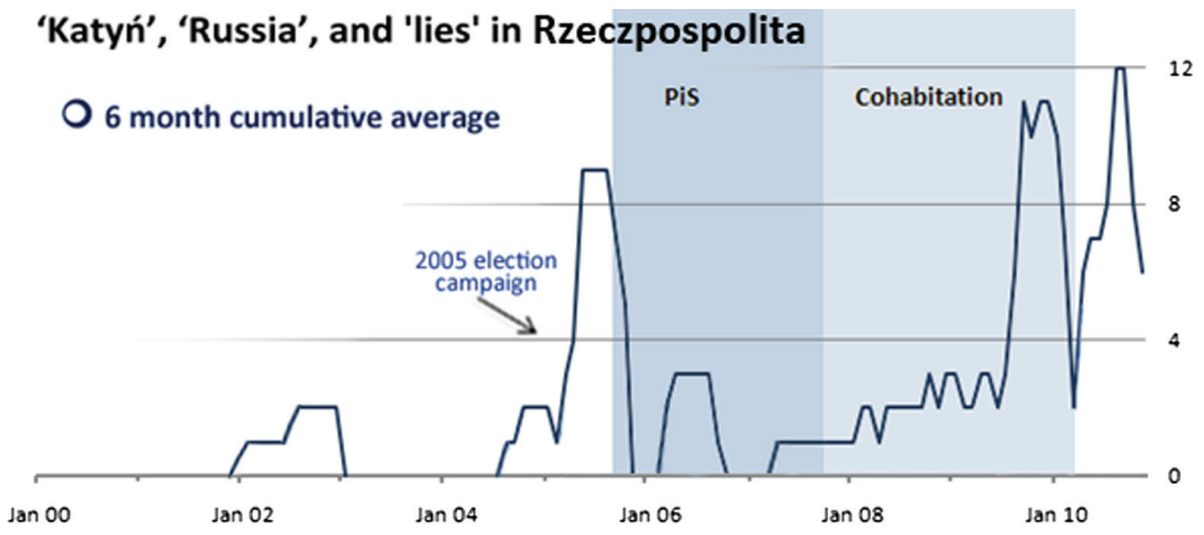

FIGURE 5. DiscuRsive CHANGE IN RZECZPOSPOLITA RHETORIC (JANUARY 2000-MARCH 2010). 
TABLE 5

Discursive Change in Rzeczpospolita Rhetoric (January 2000-March 2010): Articles Critical Of Russia

\begin{tabular}{lc}
\hline & Cumulative \\
\hline Cohabitation & $4.45^{* * *}$ \\
Left-wing government & $1.58^{*}$ \\
PiS government & 0.36 \\
Poland in EU & 0.83 \\
Russian-Polish crisis & 0.84 \\
Run-up to state visit & -0.03 \\
State visit \& no crisis & 0.13 \\
State visit \& crisis & $4.81^{* * *}$ \\
Tension \& no state visit & $2.35^{*}$ \\
Russia in Gazeta Wyborcza & $-0.04^{* * *}$ \\
April commemorations & -0.20 \\
5-year commemorations & 0.78 \\
WWII commemorations & 0.28 \\
Campaign & $2.06^{* *}$ \\
Change of government & 1.11 \\
Election aftermath & $-1.66^{*}$ \\
Wajda's Katyn & -0.93 \\
Wajda's Katyn (lag) & -0.34 \\
Constant & $3.25^{* * *}$ \\
Adjusted R squared & 0.531 \\
\hline
\end{tabular}

$* \mathrm{p}<0.05, * * \mathrm{p}<0.01, * * * \mathrm{p}<0.001$

show that this discourse increased most sharply after PiS left government (a cohabitation coefficient of 4.45). The discourse was also in evidence during left-wing governments, showing that it was specifically mobilised as part of an opposition strategy. The finding that antagonistic discourse fulfilling the function of othering is activated to coincide with elections is evidence in favour of hypothesis $1 \mathrm{~A}$, while the fact that such discourse was most attractive to PiS when in opposition supports hypothesis $1 \mathrm{~B}$.

Hypothesis 1A suggested that Katyn might have been invoked as a legitimisation strategy. Survey data show that one effect of PiS's historical policies has been a polarisation of the Polish electorate: in early 2005, before PiS entered government, the opinion polling institute CBOS (Centrum Badania Opinii Spotecznej) found Poles' assessment of PolishRussian relations to be unrelated to political affiliation (Strzeszewski 2005, p. 6). By 2009 PO voters were significantly more optimistic regarding Polish-Russian relations than were PiS voters, and in 2010 three times as many PiS voters believed good relations between the countries were impossible (Feliksiak 2010). Voters' assessment of current relations also varied according to party lines, with PO voters more likely to categorise bilateral relations as good. It is clear that PiS's marketing of itself as an anti-communist party along with a hostile relationship to Russia allowed the party to emerge with a cohesive ideology. The above findings support the hypothesis that PiS employed Katyn as a mobilising strategy. The party appears also to have used Katyn to give credence to the idea of an anti-communist IV Republic. Evidence suggesting that the aggressive discourse used is associated predominantly with one party and is distributed predominantly outside their term in government suggests that invoking contested memory is a strategy more advantageous when in opposition, as claimed in hypothesis $1 \mathrm{~B}$. 


\section{Conclusions}

The study of how Katyn features in Polish discourse set out to test two hypotheses, one suggesting Katyn's role in discourse should be relatively stable, the other suggesting contested memories were mobilised for domestic gains, especially by opposition parties. The evidence presented in this article supports the alternative hypotheses; Katyn has been debated at periods coinciding with foreign-political events, but the debate has revolved around the role Katyn should occupy in national identity. A finding of this study is that memory conflicts are the most visible when between state-level actors, but that their cause may lie in domestic political struggles. International memory conflicts may therefore be analysed profitably in connection with internally disputed identities which as Vermeersch has argued, are a consequence of a fluid party landscape where populism is a strategy employed to clarify lines of division between post-communist parties (Vermeersch 2010). This study suggests that the literature examining state-level memory disputes should consider the degree to which international memory conflicts are fuelled by domestic identity conflicts. The current high-level memory squabbles observed across Eastern Europe may be a transient phenomenon if they emerged as part of post-communist elites seeking ideological differentiation in a 'flat' party landscape.

Joanna Gorska, in her work on Polish-Russian relations, found realism to characterise Polish-Russian relations, while Katyn figured as a 'soft-case' for the importance of ideas in foreign policy (Gorska 2007, 2010). The findings presented in this study partly endorse Gorska's contention: PiS certainly invoked the memory of Katyn, but their objectives were not foreign political ones. PiS were significantly less likely to draw implications hostile to Russia from Katyn during their time in office, and more likely to do so in the run-up to elections. This study revealed that government actors are rarely the ones pushing the question of Katyn; instead ruling elites acted in response to more radical positions adopted by the domestic opposition. Constructivism, then, is in this case better suited to analysing the domestic political situation than Polish-Russian relations. These results, coupled with opinion poll data showing that invoking Katyn is popular, indicate that contested narratives do serve a mobilising function. This is not the only function, as the invocation of Katyn during the period of cohabitation shows-here PiS used the foreign political sphere in order to subvert the government's more accommodating policy and to emerge as the upholders of the national interest. The evidence regarding the timing of antagonistic discourse is telling: if Katyn's position in foreign policy was stable then it should have been on the agenda regardless of the security and energy concerns that often underlie Polish-Russian crises. However, Katyn is much more likely to be hotly debated at times of difficult relations with Russia than during good ones, suggesting that elites calculate that if relations are bad, hostile rhetoric will not have external costs but may come with domestic gains.

\section{University of Cambridge}

\section{References}

Adamska, J. (2005) 'Między dwoma wrogami', Rzeczpospolita, 16 April, available at: http://archiwum.rp.pl/ artykul/541509-MIEDZY-DWOMA-WROGAMI.html, accessed 29 March 2011.

Aggestam, L. (1999) Role Conceptions and the Politics of Identity in Foreign Policy, ARENA Working Papers, 99/8 (Bury St Edmunds, Arena), available at: http://www.deutsche-aussenpolitik.de/resources/ seminars/gb/approach/document/wp99_8.htm, accessed 13 February 2011. 
Anderson, B. (1983) Imagined Communities: Reflections on the Origin and Spread of Nationalism (London, Verso).

Assmann, J. \& Czaplicka, J. (1995) ‘Collective Memory and Cultural Identity', New German Critique, 65, pp. $125-33$.

Bachmann, K. (2006) 'Die List der Vernunft: Populismus und Modernisierung in Polen', Osteuropa, 56, pp. $11-12$.

Barth, F. (1969) Ethnic Groups and Boundaries (Boston, MA, Little, Brown).

Bartoszewski, W. \& Süssmuth, H. (2008) Polen 2008: Kurswechsel mit Donald Tusk (Düsseldorf, DUP Düsseldorf University Press).

Brüggemann, K. \& Kasekamp, A. (2008) 'The Politics of History and the "War of Monuments" in Estonia', Nationalities Papers, 36, 3, pp. 425-48.

Burch, S. \& Smith, D. (2007) 'Empty Spaces and the Value of Symbols: Estonia's "War of Monuments" from Another Angle', Europe-Asia Studies, 59, 6, pp. 913-36.

Connerton, P. (1989) How Societies Remember (Cambridge, Cambridge University Press).

Cruz, C. (2000) 'Identity and Persuasion: How Nations Remember Their Pasts and Make Their Futures', World Politics, 52, 3, pp. 275-312.

De Bruyn, D. (2010) 'World War 2.0: Commemorating War and Holocaust in Poland through Facebook', Digital Icons: Studies in Russian, Eurasian and Central European New Media, 4, pp. 45-62.

Domagalski, M. (2009) 'Katyń nie zasługuje na publicystyczne spekulacje', Rzeczpospolita, 11 September, available at: http://prawo.rp.pl/artykul/362044-Katyn-nie-zasluguje-na-publicystyczne-spekulacje-.html, accessed 18 March 2011.

Etkind, A. (2010) 'The Hera Project Memory at War', available at: http://www.hnet.org/announce/show.cgi? ID=174107, accessed 31 March 2011.

Etkind, A., Finnin, R., Blacker, U., Fedor, J., Lewis, S., Mälksoo, M. \& Mroz, M. (2012) Remembering Katyn (Cambridge, Polity).

Feliksiak, M. (2010) 'Opinie o stosunkach polsko-rosyjskich', Centrum Badania Opinii Społecznej report BS/74/2010, available at: www.cbos.pl/SPISKOM.POL/2010/K_074_10.PDF, accessed 8 March 2011.

Fischer, B. B. (2000) 'The Katyn Controversy: Stalin's Killing Field', Studies in Intelligence, Winter 1999-2000.

Fitzgibbon, L. (1972) The Katyn Cover-Up (London, Tom Stacey).

Gellner, E. (2008) Nations and Nationalism (New York, NY, Cornell University Press).

Gerhardt, S. (2007) Polska polityka wschodnia: die Aussenpolitik der polnischen Regierung von 1989 bis 2004 gegenüber den östlichen Nachbarstaaten Polens (Russland, Litauen, Weissrussland, Ukraine) (Marburg, Herder Institut).

Gil, A. \& Kapuśniak, T. (2009) Polityka wschodnia Polski: uwarunkowania, koncepcje, realizacja (Lublin, Instytut Europy Środkowo-Wschodniej).

Gmyz, C. (2010) '10 lat IPN na straży pamięci', Rzeczpospolita, 8 October, available at: http://www.rp.pl/ artykul/55271,546505_10-lat-IPN-na-strazy-pamieci.html, accessed 29 March 2011.

Gmyz, C. \& Stróżyk, J. (2009) 'Polacy: twardo o Katyniu', Rzeczpospolita, 14 September, available at: http:// www.rp.pl/artykul/99645,363363_Polacy_twardo_o_Katyniu_.html, accessed 14 September 2009.

Gorska, J. A. (2007) Dealing with a Juggernaut: Analysing Poland's Policy Towards Russia, 1989-2004, $\mathrm{PhD}$ thesis, University of Oxford.

Gorska, J. A. (2010) Dealing with a Juggernaut: Analysing Poland's Policy Towards Russia, 1989-2009 (Lanham, MD, Lexington Books).

Habermas, J. \& Derrida, J. (2003) 'February 15, or What Binds Europeans Together: A Plea for a Common Foreign Policy, Beginning in the Core of Europe', Constellations, 10, 3, pp. 291-7.

Hirst, W. \& Manier, D. (2008) 'Towards a Psychology of Collective Memory', Memory, 16, 3, pp. 183-200.

Hobsbawm, E. J. \& Ranger, T. O. (1983) The Invention of Tradition (Cambridge, Cambridge University Press).

Jepperson, R., Wendt, A. \& Katzenstein, P. (1996) Norms, Identity, and Culture in National Security (New York, NY, Columbia University Press).

Kaczyński, A. (2005a) 'Zbrodnia, kłamstwo, milczenie, prawda', Rzeczpospolita, 16 April, available at: http:// www.rzeczpospolita.pl/dodatki/dodatek1_050416/dodatek1_a_4.html, accessed 3 March 2011.

Kaczyński, A. (2005b) 'Tylko prawda', Rzeczpospolita, 18 April, available at: http://archiwum.rp.pl/artykul/ 541885.html, accessed 3 March 2011.

Kaczyński, J. (2006) 'Tekst występienia Jarosława Kaczyńskiego w debacie o 100 dniach rzędu Kazimierza Marcinkiewicza', Gazeta.pl, 17 February, available at: http://wiadomosci.gazeta.pl/wybory2005/ 1,67805,3169952.html, accessed 29 March 2011.

Kaczyński, L. (2009) 'Kaczyński: Prawda jest jedna, choć często bywa bolesna', Rzeczpospolita, 1 September, available at: http://www.rp.pl/artykul/357111.html, accessed 29 September 2011. 
Kangaspuro, M. (2010) 'Constructing Russian Identity in the Media: Between the History of WWII and the Future of Europeanness', available at: http://www.helsinki.fi/aleksanteri/english/projects/constructing.htm, accessed 31 March 2011.

Kisielewski, T. A. (2008) Katyn: zbrodnia i kłamstwo (Poznań, Dom Wydawniczy REBIS).

Kołakowska, D. (2009) 'Kiedy w Sejmie o ataku ZSRR', Rzeczpospolita, 14 September, available at: http:// www.rp.pl/artykul/363049.html, accessed 29 March 2011.

Kosicki, P. H. (2011) 'Polish Memory of Katyn, 1943-2010', Memory at War Inaugural Workshop, King's College, Cambridge, 4-5 June, abstract available at: http://www.memoryatwar.org/publications-list/ piotr-kosicki-abstract.pdf, accessed 3 May 2014.

Kubiak, P. \& Wybranowski, W. (2009) 'Co powiedzę prezydent i premier', Rzeczpospolita, 1 September, available at: http://www.rp.pl/artykul/356744.html, accessed 29 March 2011.

Kurczab-Redlich, K. (2005) 'Dokęd prowadzi nas Putin', Rzeczpospolita, 14 May, available at: http://archiwum. rp.pl/artykul/546700.html, accessed 29 March 2011.

Kuźniar, R. (2001) Poland's Security Policy 1989-2000 (Warsaw, Scholar).

Kuźniar, R. (2009) Poland's Foreign Policy after 1989 (Warsaw, Scholar).

Lacan, J. (1977) Écrits: A Selection (London, Tavistock/Routledge).

Larsen, H. (1997) Foreign Policy and Discourse Analysis: France, Britain and Europe (London, Psychology Press).

Łętowski, M. (2005) 'Moskwa nie wierzy łzom’, Rzeczpospolita, 30 April, available at: http://archiwum.rp. pl/artykul/544247-Moskwa-nie-wierzy-lzom.html, accessed 3 March 2011.

Lisicki, P. (2009) 'Ile zrozumiał Władimir Putin', Rzeczpospolita, 1 September, available at: http://www.rp. pl/artykul/357145.html, accessed 29 March 2011.

Lisicki, P. (2011) 'O Rzeczpospolitej', Rzeczpospolita, 1 January, available at: http://www.rp.pl/temat/ 194245.html, accessed 29 March 2011.

Madera, A. J. (2003) Polska polityka zagraniczna: Europa Środkowo-Wschodnia 1989-2003 (Kraków, Firma 'Sas' Wanda Tarnawska).

Maj, E. \& Wójcik, A. (2008) Myśl polityczna w Polsce po 1989 roku: wybrane nurty ideowe (Lublin, Wydawn, Uniwersytetu Marii Curie-Skódowskiej).

Majda, A. (2005) 'Rosyjska riposta na spot', Rzeczpospolita, 13 May, available at: http://archiwum.rp.pl/ artykul/546582.html, accessed 29 March 2011.

Manys, K. (2009) 'Sejm przemilczy napaść Sowietów-przez kłótnię', Rzeczpospolita, 12 September, available at: http://www.rp.pl/artykul/362147.html, accessed 29 March 2011.

Markowski, R. (2006) 'The Polish Elections of 2005: Pure Chaos or a Restructuring of the Party System?', West European Politics, 29, 4, pp. 814-32.

Marzec, B. (2005) 'Lata walki o prawdę', Rzeczpospolita, 16 April, available at: http://archiwum.rp.pl/ artykul/541524-Lata-walki-o-prawde.html, accessed 27 February 2011.

Maull, H., Stahl, B., Boeckle, H., Jöhannisdottir, A. \& Nadoll, J. (2002) 'Abschlussbericht des DFGgeförderten Projekts: "europäische Außenpolitik im dynamischen Mehrebenensystem"', available at: http://www.bernhard-stahl.de/docs/pafe_bericht.pdf, accessed 17 March 2011.

McHoul, A. W. (1993) A Foucault Primer: Discourse, Power, and the Subject (New York, NY, NYU Press).

Montfort, H. D. (1966) Le massacre de Katyn, crime russe ou crime alleman? (Paris, La Table Ronde).

Neumann, I. B. (2002) 'Europe's Post-Cold War Memory of Russia: cui bono?', in Müller, J. W. (ed.) Memory and Power in Post-war Europe: Studies in the Presence of the Past (Cambridge, Cambridge University Press).

Nikiporets-Takigawa, G. (2013) 'War of Memories in the Ukrainian Media: Diversity of Identities, Political Confrontation, and Production Technologies', in Rutten, E., Zvereva, V. \& Fedor, J. (eds) Memory, Conflict and Social Media: Web Wars in Post-Soviet States (London, Routledge).

Olick, J. K. (2008) “'Collective Memory”: A Memoir and Prospect', Memory Studies, 1, 1.

Olick, J. K., Vinitzky-Seroussi, V. \& Levy, D. (eds) (2011) The Collective Memory Reader (New York, NY, Oxford University Press).

Ordyński, J. (2005) 'Dali świadectwo prawdzie', Rzeczpospolita, 16 April, available at: http://archiwum.rp. pl/artykul/541628-Dali-swiadectwo-prawdzie.html, accessed 29 March 2011.

PAFE (2003) 'Outline of the PAFE Project', available at: http://www.bernhard-stahl.de/docs/pafe_idea_en.pdf, accessed 17 September 2010.

Pankowski, K. (2010) 'Polacy o uroczystościach w Katyniu i udziale w nich premiera Rosji', Centrum Badania Opinii Społecznej report BS/46/2010, available at: www.cbos.pl/SPISKOM.POL/2010/K_046_ 10.PDF, accessed 8 March 2011.

Paul, A. (2010) Katyn: Stalin's Massacre and the Triumph of Truth (DeKalb, IL, Northern Illinois University Press).

PiS (2003) 'Konstytucja IV Rzeczypospolitej', 19 March, available at: http://www.pis.org.pl/doc.php? $\mathrm{d}=$ unit\&id=7, accessed 28 February 2011. 
Piwowar, M. (2009) 'Stalin chciał pomóc Hitlerowi', Rzeczpospolita, 20 August, available at: http://www.rp. pl/artykul/351644.html, accessed 29 March 2011.

Prus, J. (2009) 'Moskwa wysyła sprzeczne sygnały', Rzeczpospolita, 1 September, available at: http://www. rp.pl/artykul/356733.html, accessed 29 March 2011.

Przewoźnik, A. \& Adamska, J. (2010) Katyn. Zbrodnia, prawda, pamięć (Warszawa, Świat Księżki).

Radziwinowicz, W. (2009) 'Rosja, która nie kłamie', Gazeta Wyborcza, 25 August, available at: http:// wyborcza.pl/1,76842,6961011,Rosja_ktora_nie_klamie.html, accessed 27 September 2010.

Rupnik, J. (2007) 'From Democracy Fatigue to Populist Backlash', Journal of Democracy, 18, 4, pp. 17-25.

Said, E. (1978) Orientalism (London, Routledge).

Sandecki, M. (2009) 'Prezydent na Westerplatte: Katyn jak holocaust', Gazeta Wyborcza, 1 September, available at: http://wyborcza.pl/1,76842,6987235,Prezydent_na_Westerplatte_Katyn_jak_holokaust. html, accessed 2 July 2010.

Sanford, G. (2005) Katyn and the Soviet Massacre of 1940: Truth, Justice, and Memory (London, Routledge).

Smith, S. (2001) 'Foreign Policy is what States Make of it: Social Construction and International Relations Theory', in Kubálková, V. (ed.) Foreign Policy in a Constructed World (Armonk, NY, M.E. Sharpe), pp. $38-55$.

Śpiewak, P. (2003) 'Koniec złudzeń', Rzeczpospolita, 23 January, available at: http://archiwum.rp.pl/artykul/ 419180.html, accessed 29 March 2011.

Stahl, Z. \& Anders, W. (1965) The Crime of Katyn: Facts \& Documents (London, Polish Cultural Foundation).

Stahl, Z., Anders, W. \& Sendy, J. (1949) Katyn (Paris, Polish Cultural Foundation).

Stróżyk, J. (2008) 'Zginęły dokumenty w sprawie Katynia?', Rzeczpospolita, 9 July, available at: http:// archiwum.rp.pl/artykul/791694.html, accessed 29 March 2011.

Stryker, S., Owens, T. J. \& White, R. W. (2000) Self, Identity, and Social Movements (Minneapolis, MN, University of Minnesota Press).

Strzelczyk, J. (2002) Ucieczka ze Wschodu: Rosja w polskiej polityce, 1989-1993 (Warszawa, Rytm).

Strzeszewski, M. (2005) 'Opinie o udziale Prezydenta RP w uroczystościach 9 maja w Moskwie i stosunkach polsko-rosyjskich’, Centrum Badania Opinii Społecznej report BS/76/2005, available at: www.cbos.pl/ SPISKOM.POL/2005/K_076_05.PDF, accessed 8 March 2011.

Strzeszewski, M. (2008) 'Opinie o polityce zagranicznej rzędu i Prezydenta', Centrum Badania Opinii Społecznej report BS/151/2008, available at: www.cbos.pl/SPISKOM.POL/2008/K_151_08.PDF, accessed 8 March 2011.

Szacka, B. (2006) Czas przeszty-pamiéćmit (Warszawa, Scholar).

Terlikowski, T. P. (2009) 'Negacjonizm po polsku', Rzeczpospolita, 15 September, available at: http://www. rp.pl/artykul/363470.html, accessed 29 March 2011.

Trznadel, J. (1994) Powrót rozstrzelanej armii: Katyn: fakty, rewizje, poględy (Lublin, Antyk).

Uhlig, D. (2009) 'PiS atakuje Tuska za Putina', Gazeta Wyborcza, 2 September, available at: http://wyborcza. pl/1,76842,6995462,PiS_atakuje_Tuska_za_Putina.html, accessed 2 July 2010.

Vachudova, M. A. (2008) 'Centre-Right Parties and Political Outcomes in East Central Europe', Party Politics, 14, 4.

Vermeersch, P. (2010) 'Contesting Europe: Strategies and Legacies in Polish Political Competition', EuropeAsia Studies, 62, 3, pp. 503-22.

Waever, O. (1995) 'Identity, Integration and Security: Solving the Sovereignty Puzzle in EU Studies', Journal of International Affairs, 48, 2, pp. 389-431.

Wendt, A. (1994) 'Collective Identity Formation and the International State', The American Political Science Review, 88, 2, pp. 384-96.

Wendt, A. (1999) Social Theory of International Politics (Cambridge, Cambridge University Press).

Wildstein, B. (2009) 'Partyjne rachuby ponad rację stanu', Rzeczpospolita, 13 September, available at: http:// www.rp.pl/artykul/362911.html, accessed 29 March 2011.

Wilson, A. (1995) 'The Donbas between Ukraine and Russia: The Use of History in Political Disputes', Journal of Contemporary History, 30, 2.

Wolsza, T. (2008) 'Katyn to już na zawsze katy i katowani': w 'polskim Londynie' o sowieckiej zbrodni w Katyniu (1944-1956) (Warszawa, Instytut Historii PAN).

Wybranowski, W. (2009) 'Prezydent mówił o ludobójstwie', Rzeczpospolita, 18 September, available at: http:// www.rp.pl/artykul/365065.html, accessed 29 March 2011.

Zdort, D. (2008) 'Upudrowana historia', Rzeczpospolita, 16 September, available at: http://www.rp.pl/ artykul/191692.html, accessed 29 March 2011.

Zychowicz, P. (2009) 'List Putina to wysublimowana prowokacja', Rzeczpospolita, 1 September, available at: http://www.rp.pl/artykul/356732.html, accessed 29 March 2011. 